\title{
Features of translation transformations in film titles as a linguoculturological specificity of the language
}

\author{
Anna Kaneeva $^{1 *}$, and Tatyana Bagdasaryan ${ }^{1}$ \\ ${ }^{1}$ Don State Technical University, 1, Gagarina, Rostov-on-Don, 344000, Russia
}

\begin{abstract}
The article offers a classification of translation techniques based on the analysis of Russian-language titles of foreign films. The choice of film titles as the research material is due to the greatest complexity of their translation in comparison with other texts. this opens up wide opportunities for studying translation transformations as a reflection of the linguistic and cultural specifics of the language. In the name of any film, linguistic and cultural features are understandable only to a native speaker play an important role. However, some must necessarily be translated into another language, while preserving the originality, attractiveness and capacity. All this forces the interpreter to search for and use translation transformations more actively than when working with other texts. The article deals with various types of transformations associated with the need for linguistic and cultural reinterpretation of the text in the cultural space of the recipient country. The use of linguistic and cultural studies allows us to more fully and accurately convey to the consciousness of perceiver the semantic content of the film, starting with its name, taking into account the inclusion of the translation in the cultural archetypes and codes of the native language.
\end{abstract}

\section{Introduction}

Nowadays cinema has a huge influence on contemporary art, world perception and human development today. Its place stands at the forefront among other forms of art in the XX century was almost indisputable. It should be noted that in the XXI century, the position was slightly lost due to the rapidly developing world of computer games, which, unlike cinema, made it possible for participants not only and not so much to watch what was happening on the screen, but also to become full participants. Recently, social networks, which allow users to create their own content, have also become important competitors, which often turns out to be much more popular than the works of famous masterpieces. Nevertheless, it must be recognized that cinema, despite all the challenges it faces, remains one of the most beloved art form, preferred leisure activities and communication.

One of the most significant achievements of cinema is that it is a fairly easy-tounderstand art form, and it plays a leading role in the globalization of culture. It is the

\footnotetext{
*Corresponding author: m_anna7@mail.ru
} 
widespread distribution of films that allows people in different parts of the world to get acquainted with them and be aware of new trends, styles, and fashion trends. There are no alienated spaces left in the world. But in order for the film to be viewed by various people of different nationalities who speak different languages, the film must be translated. Moreover, of course, it is necessary to clearly and accurately translate its title. This article shows that the bright and successful translation of the film title plays a leading marketing role for its distribution [1].

Linguoculturology is a fairly young science. Its appearance dates back to the 90 -s of the last century, when it became clear that the study of a language, speaking skills and using in situations requiring translation or cross-cultural interaction, is not limited to knowledge of phonetic, grammatical, lexical and syntactic rules in the space of another language. Participants in communication processes need to be aware that the picture of the world, as well as the linguistic distinctions of the interlocutors, can differ significantly, and this determines the task for interpreters to find mutual agreement in the details of the perception among representatives in different ethnic groups. Knowledge and understanding of these features is a necessary thing for the success in a communicative act. Awareness of these language points allows to have high-quality communication in individual situations, as well as to solve various global issues in the field of economy, culture, politics, settling military conflicts and disputed territorial contradictions [2].

\section{Materials and method}

The founders of this segment in linguistics can be called V. G. Kostomarov, E. M. Vereshchagin and V. V. Vorobyov. In the work of V. G. Kostomarov and E. M. Vereshchagin "Linguistic problems of country studies in teaching Russian to foreigners", a research direction was announced, which was called "linguistic and country studies". The main goal was stated as the achievement of language competence based on the knowledge and use of country-specific facts [3, 4]. The term "linvoculturology" has gained sufficient popularity. This term was introduced by V. V. Vorobyov, who developed this direction intensively together with his scientific school [5]. It should be noted that the very global size of the issue does not allow us to cover all areas of human language activity. However, a methodology that emphasizes the inclusion of cultural archetypes, codes, and metaphors in the study of a particular language is undeniably attractive. It is also relevant, since in a rapidly changing world there are new trends, scientific achievements, and their entry into practical and everyday life, which is always reflected in the language. Linguoculturology itself implies a very broad view of the problem, covering a wide variety of aspects. One of them is the linguistic and cultural reflection in translation. This can apply to everything. This article uses the methods of translation studies with a focus on translation transformations and linguistic and cultural reinterpretation.

The research material to conduct the study is the films' titles that have gained wide interest among Russian viewers. In the name of any film, an important role play linguistic and cultural features that are understandable only to a native speaker, but which must necessarily be transferred to another language, while preserving the originality, attractiveness and capacity. All this forces an interpreter to search for and use translation transformations more actively than when working with other texts. This also makes the film titles the best material for studying translation transformations, which is a reflection of the linguistic and cultural specifics of the language. It can be argued that the title of the film requires a special translation than other types of titles. The main translation transformations change according to the needs of a certain period of time and its trends, new translation approaches always correspond to the realities of a particular time. The article uses the method of constructing a classification based on the analysis of translations of film titles. 
The division into classes is based on the types of translation transformation identified in the process of analyzing the translation of films in relation to their original titles. In this article we consider the translations of film titles which were selected from the following sites: kinopoisk.ru, culture.ru, ivi.ru, we used complete sampling method.

\section{Results}

The linguistic and cultural reinterpretation of the translation of film titles allows us to identify the linguistic and cultural characteristics of a particular country, as well as to identify new translation trends within a certain period of time. The main issue of this problem is currently the problem of compatibility of the cultural code and language, which is reflected in the level of translatability. The question that is still considered one of the most relevant in the theory and practice of translation has been repeatedly raised. This is a question about the possibility of a full-fledged one-hundred-percent implementation of an equivalent translation in two different languages. It seems that by offering a variety of options for translation, the interpreter, inevitably remains the bearer of his cultural code and his understanding of the world, including the language. At the same time, creating a new updated view of the world, transferred from another language, he inevitably experiences the impact of his own linguistic and cultural ideas.

The concept of the linguistic-ethnic barrier indicates that in the process of translation, various ethno-cultural points constantly arise, which are difficult for representatives of another culture to understand, and sometimes impossible for high-quality translation. In this situation, it is necessary to use the extralinguistic components of both languages, the source language and the receptor language. On the one hand, an interpreter, or a localizer, as a translator of film titles directly, must comprehensively and systematically represent not only the linguistic structure of the source language, but also know and understand at a high level certain nuances of the mentality, the native speakers' worldview and the means to express it at all levels of the language. Moreover, it is necessary for the interpreter to be aware of the cultural, social, and humanitarian context of a certain current moment, which makes it possible to use certain language resources and extralinguistic references to convey the title of the film.

If the barrier between ethno-cultural societies appears due to the fact that their representatives express their thoughts in their usual way, then in order to cross this barrier, an interpreter is needed. Since it is the interpreter who has knowledge of the linguistic features of both sides and is able to convey information from the addressee to the recipient with minimal loss in the semantic component of the message. Thus, the linguistic-ethnic barrier is the fundamental reason for the translation process itself, in which one of the components is paraphrasing, that is, rethinking the elements of the text and presenting it in a slightly different form. This indicates the inclusion of equivalent and informative elements in the translation.

Cross-cultural communication should assume the presence of certain knowledge and the ability to apply it in practice within the rules and norms of behavior in a particular ethnocultural society, taking into account the peculiarities of its mentality. Problems of misunderstanding, as well as certain cultural characteristics of ethnic groups, provide a wide field for the exchange of cultural aspects, but unprofessional interpretation of the transmitted information often leads to conflict situations, the solution of which may require additional efforts.

In the theory of cross- cultural communication, special categories have been developed, with the help of which it is possible to characterize the distinctive features of cultures and to detect differences between them. They include the system of verbal and nonverbal communication; awareness of oneself and environment; food and rules of behaviour at the 
table; clothing and appearance; time and its perception; norms and values; relationships; mental activity and learning methods; work organization and attitude to work; a system of religious beliefs [6].

In the process of translation, the interpreter must neutralize the linguistic-ethnic barrier and prevent the violation of semantic perception. At the same time, he should not allow the national-cultural assimilation of the translation, so that "the person does not lose his national-cultural identity in the process of communication". To successfully perform such a task, a specialist must have a certain set of translation modifications and transformations. It would also be better for him to add additional explanatory information to the translation text, or use notes [7].

So, the interpreter does not just transform the text from one language into another one. He must be familiar with the range of linguistic and cultural features of the language, and when confronted with different representations of linguistic and cultural reality, he should offer ideas that correspond to the language and are understandable to the viewer.

The analysis of the film titles translation studied by the continuous sampling method and the various transformations made it possible to develop a classification of translation techniques based on comparative, empirical and analytical approaches. The classification is presented in Table 1.

Table 1. Classification of translation techniques.

\begin{tabular}{|c|c|c|}
\hline $\begin{array}{l}\text { Translation method / type of translation } \\
\text { transformation }\end{array}$ & $\begin{array}{l}\text { Percentage / } \\
\text { quantity ratio }\end{array}$ & $\begin{array}{l}\text { Movie titles (Russian translation and the original } \\
\text { title) }\end{array}$ \\
\hline 1. "Contextual-interpretive translation" & $93,32 \%$ & $\begin{array}{l}\text { 1) "The Romance of Versailles" - «A little chaos» } \\
\text { 2) "Boyfriend from the future" - «About time" }\end{array}$ \\
\hline 2. "Variant matching" & $68 \quad, 22 \%$ & $\begin{array}{c}\text { 1) "Up" }-\ll \mathbf{U p} » \\
\text { 2) “A law-abiding citizen" }-\ll \text { Law abiding Citizen» }\end{array}$ \\
\hline 3. "Genre translation" & $37,12 \%$ & $\begin{array}{l}\text { 1) "Azure shore"- } \text { «By the sea» } \\
\text { 2) "Real ghouls"- «What we do in the shadows» }\end{array}$ \\
\hline 4. "Transcriptions / Transliterations" & $24 \quad, 8 \%$ & $\begin{array}{l}\text { 1) "Sinister" }- \text { - «Sinister» (means evil, ominous) } \\
\text { 2) "Interstellar" - «Interstellar» (means intergalactic) }\end{array}$ \\
\hline 5. "The complication technique" & $21 \quad, 7 \%$ & $\begin{array}{l}\text { 1) "The Croods Family" - «The Croods» } \\
\text { 2) "Ernest and Celestine: } \\
\text { Adventures of the mouse and the bear"- «Ernest et } \\
\text { Celestine» }\end{array}$ \\
\hline $\begin{array}{l}\text { 6. "Transformation at the } \\
\text { stylistic level" }\end{array}$ & $20,6,5 \%$ & $\begin{array}{l}\text { 1) "Between heaven and earth" - «Just like } \\
\text { Heaven»" } \\
\text { 2) "A cold Heart"- «Frozen» }\end{array}$ \\
\hline 7. "Only equivalent» & $16 \quad, 5 \%$ & $\begin{array}{l}\text { 1) "Prisoners" - «Prisoners» } \\
\text { 2) "Gravity" - «Gravity»" }\end{array}$ \\
\hline $\begin{array}{l}\text { 8. Transformation at the } \\
\text { grammatical level: } \\
\text { a) Morphological transformations } \\
\text { b) Syntactic transformations }\end{array}$ & $16 \quad, 5 \%$ & $\begin{array}{l}\text { 1) "War of the Worlds "Z" - «World War Z»" } \\
\text { 2) "Game without rules" - «Fair game» }\end{array}$ \\
\hline 9. "The "Omission technique" & $7 \quad, 2 \%$ & $\begin{array}{l}\text { 1) "The first revenger" - «Captain America: the } \\
\text { first revenger» } \\
\text { 2) "Ralph" - «Wreck-it Ralph» (destroy, break it) }\end{array}$ \\
\hline $\begin{array}{l}\text { 10. "Extralinguistic } \\
\text { transformation" }\end{array}$ & $3,1 \%$ & $\begin{array}{l}\text { 1) «2+1»- «Demain tout commence» (tomorrow it } \\
\text { all starts) } \\
\text { 2) Snow White and the Huntsman 2" (The Huntsman: } \\
\text { Winter War) - «The Huntsman: Winter`s war» }\end{array}$ \\
\hline
\end{tabular}


The developed classification reflects the current changes and trends in the process of film titles translation, and responds to the requests of the modern translation of their names. Undoubtedly, the result is a reflection of the original material that comes to our country. This material was specified in the field of languages interaction one of which is Russian. Classification that is more systematic could be based on the generalization of the transformations used in translations from a number of other languages. We should not exclude from attention the subjective aspect - the ethnocultural competence and experience of the interpreter, the depth of analytical research, certain trends in translations of the current years. At the same time, the basis has already been set, which opens up opportunities for studying the problem from different sides, providing mobility to the entire direction of studying this issue [8].

\section{Discussion}

During the process of classifying the titles of films, several linguistic and cultural features and aspects were identified. These aspects reflect the system of moral values, censorship, as well as the cultural realities of both foreign countries and the recipient country (domestic translation). We will consider and discuss these aspects in this section using specific examples. It should be noted that the trasformational features of translation are associated in some cases with the fact that in Russia, when translating, quite often try to avoid the use of colloquial vocabulary, the use of obscene vocabulary, or vocabulary with erotic overtones. The reason for this is the established traditions of the country's cinema and the accepted rules of public etiquette.

An example of replacing lexical units of an obscene character is the translation of the French film "Pour la peau d'un flic" - "For the skin of a policeman". Russian can be considered a formal equivalent of the word "ment" (cop), but this word is a linguistic and cultural reality exclusively of the Russian language, that is, it is incorrect to use it when translating the French title of a French film. Thus, it is impossible to find a decent equivalent, since the jargon names of all elements in the criminal environment and the law enforcement system that opposes it are deeply individual in each language. In this example, the lexical transformation minimise the linguistic and cultural reality of the French name.

The name of the French film "Les valseuses" in the Russian version is called "Waltzing", that is, a literal translation. While this word has a vulgar meaning in the feminine plural (Valseur-se $f, p l$ vulg. - testicles). Another striking example of the omission of the obscene meaning of the film title is the film "Snatch". A literal translation into Russian is a profanity that is unacceptable for presentation to the general public. Therefore, for Russia, the original title was simply selected based on the events of the film's plot, which is not related to the original English title - "Big Jackpot", which, by the way, has no equivalent in English.

The French film "Mes Copines" (literal translation - "My girlfriends") was radically changed by the interpreter into - "Girls above: French kiss". The title of the film has got a vulgar connotation, which was done in order to attract more of the target audience for the film - young people. It is worth noting that over the past couple of decades, some interpreters have attempted to translate movie titles using vulgar language. However, such cases are rare, and the wording of the names themselves is too ambiguous, rather than offensive to a modern audience.

One of the brightest examples is the well-known film "Only girls in Jazz", which in the original is called "Some Like it Hot". Who would have thought that the name in the original has nothing to do with the translation into Russian? Such examples vividly characterize the influence of censorship, characteristic of Soviet times. As already 
mentioned, films and other cultural works of peoples are "bridges of intercultural communication", and, consequently, interpreter are intermediaries of communication between two cultures [9-13]. This relationship has a huge responsibility on interpreters because the quality of their work largely depends on how one culture will perceive another.

In the process of translating movie titles, experts also tend to display the title in a shorter form. For example, the film "Gone girl" in Russia was released under the name "Disappeared", and the film "Law abiding Citizen" was presented as "Law-abiding citizen". This trend can be explained by the grammatical features of the English and Russian languages. Some phrases from English cannot be translated into Russian, taking into account all the grammatical and stylistic rules. It should also be noted that the longer lexical units of the Russian language, which may not always act as a bright title. It is for this reason that short English phrases (titles) are translated into Russian reflecting the main idea.

Today, the quality and living conditions of the population of many countries are significantly different from the level that was observed several decades ago. However, the process of globalization, competition, wars and other problems force people to withdraw more into themselves and escape from reality with the help of entertainment programs, the Internet and movies. In this regard, such genres as "fantasy", "science fiction" and even "horror" are becoming increasingly popular in the cinema. In order to attract viewers, modern Russian interpreters began to practice the technique of transliteration and transcription. The examples of these titles are such films as "Annihilation", "Interstellar", and "Sinister". Thus, the interpreters played on the innate curiosity of Russian viewers and pushed them to watch these films [14].

Here are some more examples of translations of movie titles. Some of them reflect the perception of time and space in Russian literature. Russian film "Never Grow Old" in the original version sounds like "Never grow up", but the Russian equivalent of this name was "Not to grow old", from which we can draw the following conclusion: in Russian, unlike English, there is a division of the concept of "getting older" (becoming an adult) (positive connotation) and "aging" (senescence)- (negative connotation). It is likely that the producer of the film meant growing up with a negative connotation, but the title in the original language is not able to express this idea more clearly than the Russian equivalent.

It is not always possible to successfully translate the concept of time, since the external design of the title in translation often expresses the main idea of the film, rather than the internal content of the original film title with its metaphorical and connotative meanings. For example, the film "Time Patrol" (predestination) - "Predestination" (2013 Peter and Michael Spierig) - was translated using the interpreted translation technique. Of course, the concept of "Predestination" is associated with the future, but this is not enough to understand what the film is about.

Another not the most successful translation option related to the connotative meaning of the lexical unit is the film "The Illusion of Deception". The original title is - "Now you see me" (2013 Louis Leterrier) that can be translated as you see/ understand me. This translation was performed on a pragmatic level with the help of an interpretive translation. This film tells the story of a group of tricksters who cheat and steal things from rich people and organizations in front of a crowd of people. It is logical that for a better understanding of the idea Russian interpreters have introduced such a lexical unit as "Illusion" into the translation, but the full form of the translated version "Illusion of deception" sounds like a tautology [15].

The following example is the title of the movie "I'm not here". This translation reflects an absolutely Russian linguistic and cultural peculiarity. This feature is expressed in a certain word order, syntactic relation, as well as cases. The Russian version of the name is 
presented in the genitive case, which in turn reinforces the "absence". Also, when considering the titles, it became clear that the title in the original language and the translated title have different semantic accents. In the original title "I'm not here", the emphasis is on the category of place - "not here", while in the translated version of the title "Me is not here", the emphasis is on the absence in general - "not here". These insignificant details create a general linguistic and cultural picture of the language with its deep aspects and realities.

One of the most prominent aspects in the translation was the replacement of the gerund in the English title with the infinitive, impersonal form of the verb in the Russian translation of the title. An example of such a replacement would be the movie "To save Mr. Banks" - "Saving Mr. Banks", whereas in the original version there is a gerund form of the verb. The gerund is a lacunar element of English language culture. Russians do not have this grammatical element, so the interpreters try to use the infinitive, which is simple and understandable to the Russian audience. It is also worth noting that the existence of such parts of speech and their absence in the language depends on the mental component of a particular linguistic and cultural society. This can explain the evasive manner of speech of the English-speaking society and the directness of the Russian-speaking person.

There are also a number of aspects that are vivid representatives of Russian cultural realities. For example, the movie "Dot the i", was translated as "Dots over i's". In Russian, there is an expression "Dot the i's", which originates from the French language, where spelling marks and dots over some vowels have a great influence on the pronunciation of the word. This French idiom appeared in the Russian language because the letter "i" was used in Russian orthography during a certain historical period. This idiom spread in Western countries and eventually took the form of "dot the i's" in English, where "dot" is a verb and means "put the dots".

Another interesting translation is the film "Huge fish" the original title is "Big Fish", where the interpreters did not resort to a literal translation ("Big Fish"), but used the consonance with the phraseological unit in the Russian language. "Big fish" in the Russian mind is associated with the highest ranks or just management, but in this case, this translation does not convey the main idea of the film.

The next title of the film "The Good lie" ("Good lie") in Russian is "A lie for salvation". Russian phraseological unit, which plays an important role in Russian culture, was used in the translation of this title. Both the original name and the Russian equivalent have a similar connotation (deception for the benefit of the deceived person), however, in Russian society, the negative concept of "lie" cannot be accompanied by positive lexical units. For this reason, the closest variant was chosen for Russia, which existed in the Russian language for a very long time and came from the incorrect use of Old Slavonic Biblical texts.

The next example of using phraseological units is the historical film: "Kingdom of Heaven". In Russian there is a stable expression "rest in peace", which is a colloquial outdated form of wishing the deceased an afterlife in paradise, was used in the translation into Russian. In this case, the title of the film has a completely different meaning. After viewing this historical picture, you can learn that the action takes place in Jerusalem, whose inhabitants called their city "The Kingdom of Heaven". According to chapter 21 of the book of Revelation, Jerusalem is a Heavenly city sent by God, whose foundation consists of all kinds of precious stones. Therefore, we can say that the Russian official translation accurately reflects the essence of the film [15].

The next original title of the film in the comedy genre is "Lemony Snicket's Series of Unfortunate Events", the official translation of which in Russia is the title "Lemony Snicket: 33 misfortunes". The difficulty in translating this film title is that the translator had to choose between five synonymous versions, one of which at the same time should be 
close to the Russian audience. That is why the translation of "33 Misfortunes" was chosen, since in the Russian language there is a phraseology that combines the meaning of all other versions of the translation of this name. The number 33 has a religious meaning. At the age of 33, Jesus Christ died, then in Russian fairy tales 33 knights with Chernomor are mentioned, Ilya Muromets sat on the stove and had been ill for 33 years. It is obvious that this figure has been fixed in the Russian mentality for a very long time and means a life experience. At the same time, since ancient times in Russia it was believed that the number 3 brings good luck, and the number 33 symbolically means "a lot, limitless" [16].

Sometimes, in order to avoid associative links with some painful historical facts for the audience, interpreters purposefully replace the name completely, or change it structurally. This translation was made over the film title "World War Z". It is not necessary to remind that the very expression "world war" is echoed in the Russian person with pain and sorrow. That is why the translation changed the syntactic relationship between the lexical units of the title, and, as a result, the title was translated as "War of the Worlds Z".

The film "L'ennemi public No. 1" ("Enemy of the State No. 1") was not translated literally, since the concept of "people's enemy" has negative associations for the Russian mentality.

A similar example of a negative association in the mind of a Russian person is the translated title of the film "Public enemies". The word "public" has several meanings: public, social, community. Whereas the word enemies means: enemy. This film could be translated as "Enemies of society", but, as already mentioned in one of the examples, the phrase "people' enemy" is not very positively perceived by the Russian-speaking audience in view of the historical aspects of the country. Therefore, the interpreters chose "Johnny D.", who is the main character and public enemy number one in this film.

Using the method of associative connections, the title of the film "New Era Z" (gifted girl) - "The girl with all the gifts" (2016 Colm McCarthy) was translated. When translating this film, a translation transformation was performed at the pragmatic level, a more specific, contextual-interpretive technique. The original title of the film "The girl with all the gifts" or "Gifted Girl" in translation into Russian does not convey the atmosphere of a post-apocalyptic dramatic zombie horror. In Russia, the translator gave the film a slightly different name - "New Era Z", where the designation Z, apparently, is a reference to the "Theory of Generations" by William Strauss.

Associative connections in the mind of every individual, of course, play a very important role. This means that these connections are strong in the minds of an entire nation. Most often, the events of the past years, historical events, wars, victories, defeats, and the pain of loss are recalled in the memory of any nation. When translating the title of the film, it is necessary to take into account these factors, so as not to offend the feelings of an individual linguistic and cultural society.

In the process of translating the film "The first revenger: Standoff" - "Captain America: Civil War" (2016 Anthony and Joe Russo), the interpreters managed to avoid using the "unfortunate" phrase "Civil War". By analogy with the first part of the film "Captain America", the title was translated using a contextual-interpretive technique. One can also see that the decoding the title of the first part took a leading role in the entire title of this release, while the interpreters omitted the name of the main character. Among other things, the second half of the title "Civil War" in translation into Russian sounds like "Civil War". However, the concept of civil war does not coincide with the plot of the film (not citizens of one country, but superheroes), but also is not welcomed by domestic linguistic and cultural realities.

Another representative of the syntactic changes is the movie "Yes man" or "Always say Yes". At the very beginning, looking at the Russian equivalent, one can note the imperative form of the title. The imperative is more inherent in Russian culture because of 
the prevailing historical events. In Russian culture, there has always been a clear division between rights. There have always been people who have no rights and people who have rights to everything. Therefore, imperative mood has always been in speech. Another more obvious reason for this translation of the name is the system of syntactic relations between lexical units that differs from the Russian one. In other words, "Yes man" is a lacunar statement, for which it was difficult to find a decent equivalent. Following the example of working with the translation of gerund forms of a word in English, an interpreter used the infinitive in the imperative form.

The film "Moneyball" for the American audience sounds quite ordinary and unremarkable ("Money / Golden Ball"), which tells about a famous manager and coach. This person changed the principle and system of payment for sportspeople in the United States. Then this system became relevant all over the world. This story is well known without further explanation to almost everyone in the United States, while for the Russian audience, some detailed explanation what awaits them in the film is necessary. Such linguistic and cultural realities of one country, of course, need to be explained, since they seem unknown to a wider global world audience, despite the importance of the events that have taken place. In addition, such a translation gave importance and nobility to the main character and created a positive image in the viewer even before the viewing [17].

Another linguistic and cultural feature of the English language, which is difficult for a Russian person to understand, is expressed in the title of the film "The Dog's Purpose". The literal translation of this unit sounds like "The purpose of the dog", as if the animal was born with a specific purpose and a clear mechanical function. This fact is soulless in relation to a living being in the understanding of the Russian audience. Surprisingly, in English-speaking cultures and in the English language in general, all animals, as well as newborn children, are classified as "it", which equates a dog to a stone, and separates a newborn child from the concept of a full-fledged person. For this reason, the Russian interpreters presented a more correct translation of the title - "Dog's life".

The latest example of linguistic and cultural features in translation can serve as some films in the genres of "horror", "thriller" or "action". The peculiarity is that recently interpreters too often use the word "curse" and other concepts of "darkness": "The cursed way" - "Road of Perdition"," The Curse of the nun " - "Nun", "The Curse of Hopewell" "Nails", "The Island of the Damned" - "Shutter Island", "The Curse of Annabelle: The Birth of Evil" - "Annabelle 63 Creation", "The Curse: Our days" - "The Cricifixion". Since ancient times, the life of the proto-Slavs, then still pagans, was built on words, spells and curses, in which there was a lot of meaning and power. The Russian linguistic and cultural community is still afraid, and sometimes even terrified of the word "curs" at the genetic level. With this information, interpreters are increasingly using these lexical units to add a certain stylistic expressiveness to the title of the "dark genre" [18].

\section{Conclusion}

During the creation and development of the classification of the existing film titles and their interpretation, several linguistic and cultural features and aspects were identified:

- $\quad$ replacing the gerund form of the verb with the infinitive;

- $\quad$ use of idioms and phraseological units that are similar in meaning to the original title;

- the desire to make the title shorter;

- $\quad$ using transliteration / transcription to keep the audience intrigued and interested;

- $\quad$ use of the connotative meaning of the word, if any;

- $\quad$ influence of inflectional language (case relations between lexical units); syntactic relations in a sentence; 
- $\quad$ replacing lacunar concepts with neutral ones;

- substitutions to avoid making associative connections with negative events or historical facts;

- translation of the title in imperative mood;

- substitutions which depend on the attitude of a particular audience to moral, religious, and material issues.

Global changes in world societies and cultures, as well as revolutionary processes in mass media, art and cinema; allow us to conclude that modern collective thinking has taken a new direction in its development. Taking into account the process of globalization, modern society has formed a different, new worldview, a system of views on certain issues, moral and ethical attitudes, interests and needs. The new time brings new trends in various spheres of creative and life activity of a person. The combination of these factors also affected the translation process. In parallel with the emergence of new nominative trends regarding the creation of a film title, the requirements for their translation have also changed.

\section{References}

1. L. Amiri, G. Fowler, Regional Studies of Russian Eastern Europe and Central Asia, 2, 297-314 (2012)

2. S. Minasian, A. Kaneeva, Guerres Mondiales et Conflicts Contemporains, 265(1), 2132 (2017), doi: 10.3917/gmcc.265.0021

3. E. Vereshchagin, V. Kostomarov, Linguistic civilization problems in Russian teaching for foreigners (Moscow, 1990), [in Russ]

4. E. Vereshchagin, V. Kostomarov, Language and Culture (Moscow, 2005), [in Russ]

5. V. Vorobyov, Cultural linguistics. Theory and methods (Moscow, 2006), [in Russ]

6. T. Mikheeva, A. Ulzytueva, N. Motorina, Journal of Entrepreneurship Education (Jee), 20(2), 258-260 (2017)

7. E. Murugova, In the European Proceedings of Social \& Behavioural Sciences EpSBS WUT, 416-425 (2018), doi:http://dx.doi.org/10.15405/epsbs.2018.04.02.59URL: https://www.futureacademy.org.uk/files/images/upload/WUT2018F59.pdf

8. E. Murugova, Book Review: Teoreticheskie i Prikladnye Aspekty Korpusnykh Issledovaniy, 16(4), 197-200 (2016), URL: https://.jvolsu.com/index.php/ru/component/attachments/download/1555

9. J. H. Lee, M. Ostwald, N. Gu, M. Roberts, International Journal of Technology and Design Education, 31(1), 165-181 (2021), doi: 10.1007/s10798-019-09544-2

10. O. Glukhova, Journal of Teaching English for Specific and Academic Purposes, 9(2), 193-203 (2021), doi: 10.22190/JTESAP2102193G

11. H. L. Eshkuvatovna, Annals of the Romanian Society for Cell Biology, 25(3), 4778$4784(2021)$

12. A.C. Turcato de Oliveira, R. Brasileira de Linguistica Aplicada, 21(1), 81-106 (2021), doi: 10.1590/1984-6398202117125

13. B. Sokhibaabdusharipovna, Annals of the Romanian Society for Cell Biology, 25(2), 3021-3027 (2021)

14. I. N. Alousque, Procedia- Social and Behavioral Sciences, 212, 237-241 (2015), https://doi.org/10.1016/j.sbspro.2015.11.339.

15. F. J. Diaz-Perez, Journal of Pragmatics 70, 108-129 (2014) 
16. T. Koshel, N. Revyakina, N. Manuilova, E. Sakharova, SHS Web of Conferences, 70, 1-5 (2019), DOI: https://doi.org/10.1051/shsconf/20197008021

17. G. Matveeva, G. Myasischev, O. Gaibaryan, E. Shirina, E3S Web of Conferences, 210, $16011 \quad$ (2020), URL: https://www.e3sconferences.org/articles/e3sconf/pdf/2020/70/e3sconf_itse2020_16011.pdf

18. T. Asten, A. Rynkevich, A. Karpova, In Proceedings of ICERI-2020 (2020), doi: 10.21125/iceri.2020.0543, https://library.iated.org/view/ASTEN2020MUL 